WSRC-RP-91-1220

DE92 040050

\title{
HAZARDOUS WASTE/MIXED WASTE TREATMENT BUILDING THROUGHPUT STUDY (U)
}

by

\author{
J. L. England and J. P. Kanzleiter
}

Westinghouse Savannah River Company

Savannah River Site

Aiken, South Carolina 29808

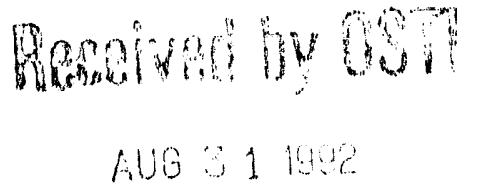

DISCLAIMER

\begin{abstract}
This report was prepared as an account of work sponsored by an agency of the Unitad States Government. Neither the United States Government nor any agency thereof, nor any of their employees, makes any warranty, express or implied, or assumes any legal liability or responsibillity for the accuracy, completeness, or usefulness of any information, apparatus, product, or process disclosed, or represents that its use would not iniringe privately owned rights. Reference hereill to any specific commercial product, process, or service by trade name, trademark, manufacturer, or otherwise does not necessarily constitute or imply its endorsement, recommendation, or favoring by the United States Government or any agency thereor. The views and opinions of authors expressed herein do not necessarily state or reflect those of the United States Government or any agensy thereof.
\end{abstract}

This report was prepared in connection with work done under Contract No. DE-AC09-89SR18035 with the U.S. Department of Energy. By acceptance of this report, the publisher and/or recipient acknowledges the U.S. Government's right to retain a nonexclusive, royalty-free license in and to any copyright covering this report, along with the right to reproduce and to authorize others to reproduce all or part of the copyrighted report. 


\section{DISCLAIMER}

This report was prepared as an account of work sponsored by an agency of the United States Government. Neither the United States Government nor any agency thereof, nor any of their employees, makes any warranty, express or implied, or assumes any legal liability or responsibility for the accuracy, completeness, or usefulness of any information, apparatus, product, or process disclosed, or represents that its use would not infringe privately owned rights. Reference herein to any specific commercial product, process, or service by trade name, trademark, manufacturer, or otherwise does not necessarily constitute or imply its endorsement, recommendation, or favoring by the United States Government or any agency thereof. The views and opinions of authors expressed herein do not necessarily state or reflect those of the United States Government or any agency thereof.

This report has been reproduced directly from the best available copy.

Available to DOE and DOE contractors from the Office of Scientific and Technical Information, P.O. Box 62, Oak Ridge, TN 37831; prices available from (615) 576-8401, FTS 626-8401.

Available to the public from the National Technical Information Service, U.S. Departinent of Commerce, 5285 Port Royal Rd., Springfield, VA 22161. 
WSRC-RP-91-1220

DECEMBER 18, 1991

REVISION 0

\title{
HAZARDOUS WASTE / MIXED WASTE TREATMENT
}

\section{BUILDING THROUGHPUT STUDY (U)}

\author{
PREPARED BY \\ JEFFERY L. ENGLAND \\ JOSEPH P. KANZLEITER \\ SYSTEMS ENGINEERING \\ ENGINEERING AND PROJECTS DIVISION \\ WESTINGHOUSE SAVANNAH RIVER COMPANY
}

DOES NOT CONTAIN UNCLASSIFIED CONTROLLED NUCLEAR INFORMATION

$A D C \& R O$

REVIEWED BY:

AUTHOR:

AUTHOR:

APPROVED BY:

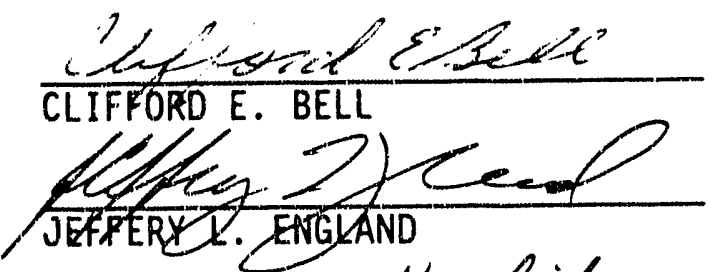

DATE: $12 / 1: 9$ DATE: 17 DeC 91 DATE: $17-\operatorname{Dec} 91$ JOSEPH P. KANZLEITEB

Lean Y. Babel for S.V. S) VENKATESH MANAGER

WASTE MANAGEMENT SYSTEMS

DATE: $12 / 17 / 91$ 


\section{TABLE OF CONTENTS}

1.0 EXECUTIVE SUMMARY .................... 3

2.0 INTRODUCTION . . . . . . . . . . . . . . . . . . . . . . . 4

2.1 Background Information ................ 4

2.2 General Assumptions................. 4

3.0 WASTE VOLUMES AND GENERATION RATES ............... 6

3.1 Wastes in Storage ................... . 6

3.2 Future Waste Generation . . . . . . . . . . . . . 7

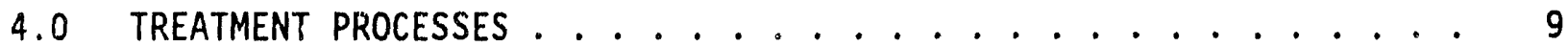

4.1 Assumptions . . . . . . . . . . . . . . . . 9

4.2 Process Description .. . . . . . . . . . . . . . . . . . . . 9

4.3 Final Treated Waste Descriptions . . . . . . . . . 21

5.0 PROCESS FLOW ....................... 23

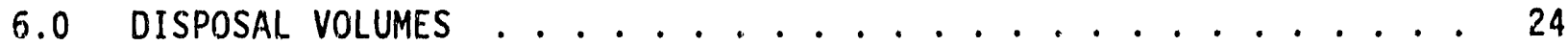

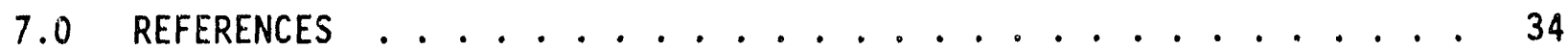

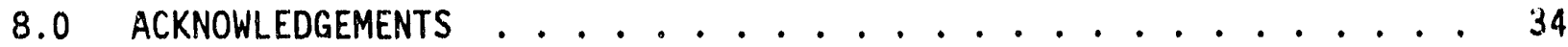


WSRC-RP-9]-1220

DECEMBER 18, 1991

REVISION 0

\subsection{EXECUTIVE SUMMARY}

The HW/MW Treatment Building (TB) is the specified treatment location for solid hazardous waste / mixed waste at SRS. This report provides throughput information on the facility based on known and projected waste generation rates.

The HW/MW TB will have an annual waste input for the first four years of approximately $38,000 \mathrm{ft}^{3}$ and have an annual treated waste output of approximately $50,000 \mathrm{ft}^{3}$. After the first four years of operation it will have an annual waste input of approximately $16,000 \mathrm{ft}^{3}$ and an annual waste output of approximately $18,000 \mathrm{ft}^{3}$. There are several waste streams that cannot be accurately predicted (e.g. environmental restoration, decommissioning, and decontamination). The equipment and process area sizing for the initial four years should allow excess processing capability for these poorly defined waste streams.

A treatment process description (section 4) and process flow (section 5) of the waste is included to aid in understanding the computations (section 6) of the throughput.

A description of the treated wastes is in section 4. 
WSRC-RP- $91-1220$

DECEMBER 18, 1991

REVISION 0

\subsection{INTRODUCTION}

\subsection{Background Information}

The Savannah River S:+. (SRS) is a Department of Energy nuclear material processing favility operated by Westinghouse Savannah River Company (WSRC) to produce plutonium and tritium for defense applications. During the production process several hazardous, radioactive, and mixed waste streams are generated. One proposed waste project is the Hazardous Waste / Mixed Waste Treatment Building (HW/MW TB). This facility will process variolss solid hazardous and mixed wastes prior to disposal in Resource Conservation and Recovery Act (RCRA) permitted disposal vaults or incineration at the Consolidated Incinerator Facility (CIF). The HW/MW TB will maintain RCRA authorized storage for received waste and treated waste awaiting transport to disposal.

\subsection{General Assumptions}

1. Each HW/MW Vault is assumed to hold either $900055 / 71$ gallon drums or 1200 B-25 sized $\left(6^{\prime} \times 4^{\prime} \times 4^{\prime}\right)$ boxes.

2. HW/MW Vaults will be available to accept stabilized/treated waste.

3. Sludges/Soils can be successfully stabilized to meet the Toxicity Characterization Leaching Procedure (TCLP).

4. Stabilization of sludges and soils will approximately double the volume of those particular waste streams.

5. Fifty (50) percent of a 17 lead in storage and generated in the future will be recycled/reused.

6. No radioactiveiy contaminated elemental mercury (RCEM) will be sent to a stockpile (i.e. all RCEM will be amalgamated and disposed in the HW/MW Vaults for the purposes of this study).

7. All process equipment treated at the HW/MW Treatment Building (TB) will be sent to the HW/MW Vault.s. 
WSRC-RP-91- 1220

DECEMBER 18, 1991

REVISION 0

8. All combustible material will be separated in the HW/MW TB sorting area and sent to the Consolidated Incinerator Facility (CIF).

9. Containers and packing material increase the volumes of incoming waste hy $25 \%$.

10. $5 \%$ of containers and packing materials are combustible by the CIF.

11. $5 \%$ of containers and packing materials are recyclable.

12. Wastes sent to the size reduction process will be reduced in volume by fifty (50) percent.

13. Spent tower packing will be direct disposed and not stabilized.

14. Gold traps will be direct disposed.

15. ITP filters will be direct disposed.

15. Shredding and soxing of combustible material will increase the waste volume by $25 \%$.

17. There is approximately $5 \% \mathrm{Cd}$ by volume in the HEPA filter frames.

18. There will be a $80 \%$ packing efficiency for all final disposal containers.

19. Waste volumes used are from previous project documents with any current updates from Waste Management included.

20. 100,000 Gallons of wastewater per year.

21. Wastewater will be generated infrequently.

22. Significant potential source of wastewater is firewater.

23. Wastewater will be $98 \% \mathrm{H}_{2} \mathrm{O}$, and $2 \%$ contaminants/solids by weight.

24. Effluent from treatment will be recycled for process use or decontamination. 
WSRC-RP-91-1220

DECEMBER 18, 1991

REVISION 0

3.0 WASTE VOLUMES AND GENERATION RATES

3.1 Wastes in Storage as of 12/91

WASTE INVENTORY TABLE FOR PROCESSING IN THE HW/WW TB

\begin{tabular}{|c|c|c|}
\hline WASTE DESCRIPTION & $\begin{array}{c}\text { NUMBER OF } \\
\text { CONTAINERS }\end{array}$ & $\begin{array}{c}\text { WASTE VOLUME } \\
\left(\mathrm{FT}^{3}\right)\end{array}$ \\
\hline CONTAMINATED LEAD & $161+$ & 17,235 \\
\hline LETF FILTER PAPER & 93 & 8,400 \\
\hline CD PLATED HEPA FILTERS & 18 & 1,400 \\
\hline CMP SOILS & $500+$ & 47,000 \\
\hline MERCURY SOILS & 5 & 450 \\
\hline FLOOR SWEEPINGS & 7 & 50 \\
\hline PROCESS BEDS & 10 & 200 \\
\hline TRITIATED EQUIPMENT & $10+$ & 700 \\
\hline PLATING LINE SUMP WASTE & 2 & 15 \\
\hline CONTAMINATED SOIL & $27+$ & $700+$ \\
\hline SPENT FILTERS & 4 & 30 \\
\hline MERCURY & $2+$ & 15 \\
\hline CONTAINERS \& & N/A & 20,000 \\
\hline PACKING MATERIALS & 8 & 60 \\
\hline SLUDGES & & \\
\hline
\end{tabular}

WASTE INVENTORY TABLE FOR DIRECT DISPOSAL IN HW/MW VAULTS

\begin{tabular}{|c|c|c|}
\hline WASTE DESCRIPTION & $\begin{array}{c}\text { NUMBER OF } \\
\text { CONTAINERS }\end{array}$ & $\begin{array}{c}\text { WASTE VOLUME } \\
\left(\mathrm{FT}^{3}\right)\end{array}$ \\
\hline $\begin{array}{c}\text { ITP FILTERS } \\
\text { (generated by } \\
\text { HW/MW startup) }\end{array}$ & $\begin{array}{c}1 \\
\text { (estimat, d) }\end{array}$ & 72 \\
\hline GOLD MERCURY TRAPS & 5 & 270 \\
\hline SPENT TOWER PACKING & 22 & 125 \\
\hline
\end{tabular}


WSRC-RP-91-1220

DECEMBER 18, 1991

REVISION 0

3.2 Future Annual Waste Generation

ANNUAL MASTE GENERATION TABLE FOR PROCESSING THROUGH THE HW/MW TB

\begin{tabular}{|c|c|c|}
\hline WASTE DESCRIPTION & $\begin{array}{l}\text { NUMBER OF } \\
\text { CONTAINERS }\end{array}$ & $\begin{array}{l}\text { WASTE VOLUME } \\
\left(\mathrm{FT}^{3}\right)\end{array}$ \\
\hline CONTAMINATED LEAD & $10+$ & 175 \\
\hline LETF FILTER PAPER & 20 & 2000 \\
\hline Cd PLATED HEPA FILTERS & 3 & 250 \\
\hline SLUDGES & UNKNOWN & $?$ \\
\hline MERCURY SOILS & UNKNOWN & $?$ \\
\hline FLOOR SWEEPINGS & 1 & 10 \\
\hline PROCESS BEDS & 1 & 20 \\
\hline TRITIATED EQUIPMENT & 1 & 100 \\
\hline F\&H BASIN SOLIDS & 55 & 5000 \\
\hline CONTAMINATED SOIL & UNKNOWN & $?$ \\
\hline SPENT FILTERS & 1 & 5 \\
\hline MERCURY & $2+$ & 15 \\
\hline $\begin{array}{c}\text { CONTAINERS \& } \\
\text { PACKING MATERIAL } \\
\end{array}$ & $N / A$ & $8000+$ \\
\hline $\begin{array}{c}\text { DECOMMISSIONING } \\
\text { \& DECONTAMINATION } \\
\text { ACTIVITIES } \\
\end{array}$ & UNKNOWN & $?$ \\
\hline CMP SOILS & UNKNOWN & $?$ \\
\hline $\begin{array}{l}\text { ENVIRONMENTAL } \\
\text { RESTORATION } \\
\text { SOILS \& SLUDGES }\end{array}$ & ¿WNKNOWN & $?$ \\
\hline
\end{tabular}


WSRC-RP-91-1220

DECEMBER 18, 1991

REVISION 0

ANNUAL WASTE GENERATION TABLE FOR DIRECT DISPOSAL IN HW/MW VAULTS

\begin{tabular}{|c|c|c|}
\hline WASTE DESCRIPTION & $\begin{array}{c}\text { NUMBER OF } \\
\text { CONTAINERS }\end{array}$ & $\begin{array}{c}\text { WASTE VOLUME } \\
\left(\mathrm{FT}^{3}\right)\end{array}$ \\
\hline ITP FILTERS & 1 & 72 \\
\hline GOLD MERCURY TRAPS & 1 & 10 \\
\hline SPENT TOWER PACKING & 1 & 5 \\
\hline
\end{tabular}


WSRC -RP - $91-1220$

DECEMBER 18,1991

REVISION 0

\subsection{TREATMENT PROCESSES}

\subsection{Assumptions}

1. The treatment processes used in this study are preconceptual processes and the actual process used in the facility may differ.

\subsection{Treatment Process Descriptions}

The processes to be included in the HW/MW TB are:

- $\quad$ Size Reduction - Size reduction allows efficient use of RCRA disposal space and assists in the repackaging of wastes to be shipped to the Consolidated Incineration Facility (CIF) and Solid Waste Disposal Facility (SWDF). Typical wastes are lead shielding, HEPA filters, and wastewater treatment filters.

- Macroencapsulation - The specific process recommended is thermoplastic polymer macroencapsulation based on regulations and SRS needs. Macroencapsulation is a specified technology for radioactive contaminated lead and could be used on other solid heavy metal wastes (by variance).

- Stabilization / Solidification - Stabilization / Solidification of wastes in a cement or polymer matrix. Sludges and soils are candidates for this process.

- Mercury Roasting/Retorting and Recovery - A specified technology for high mercury wastes ( $\mathrm{Hg}>260 \mathrm{ppm})$. The recommended method is a vacuum oven.

- Mercury Amalgamation - A specified technology for disposal of any radioactive contaminated elemental mercury. A batch system is recommended.

- Acid Leaching and Chemical Precipitation - A best demonstrated available technology (BDAT) for the removal of heavy metals from certain wastes.

- Wastewater Treatment - Any of several chemical processes treating the liquid streams generated by treatment processes, firewater, or decontamination of equipment. 
WSRC-RP-91-1220

DECEMBER 18, 1991

REVISION 0

\subsubsection{Sorting/Size Reduction Process}

The wastes scheduled to be handled by the facility are stored in a wide variety of containers. The exact contents of most waste containers are not fully known or the waste container has wastes requiring different treatment processes. As a result, a waste sorting module will be part of the HW/MW TB. After the wastes are characterized and verified some of the wastes will be repackaged for treatment at other SRS waste facilities and the rest will be treated at the HW/MW TB.

The solid mixed and hazardous wastes to be treated at the HW/MW TB will be handled ALARA (radiation exposure As Low As Reasonably Achievable). To keep unnecessary exposur'e to a minimum all wastes will be sorted into non-contact handled and contact handled. The third category of wastes, tritiated wastes, will be kept separate from all other wastes. After sorting, each waste category to be size reduced will have its own special considerations during the size reduction process.

Size reduction is not a regulatory requirement but size reduction or size standardization makes treatment prccessing more efficient and allows more wastes to be placed in the disposal vaults. There is a DOE requirement for volume reducing the amount of waste disposed and generated at $D O E$ facilities that supports the inclusion of a size reduction module.

The initial size reduction step will be to further sort wastes and then to cut wastes into process suitable sizes. Size reduction operations will be campaign processes to minimize the co-mingling of the different waste codes and to prevent treatment difficulties resulting from mixed waste codes. The size reduction equipment will be decontaminated and cleaned between campaigns to prevent co-mingling of waste codes. The specific size reduction process will depend on the waste category.

- Non-Contact Handled Wastes (NCHW)

Large wastes can be cut with mobile shears mounted on an articulated boom or crane (if 
WSRC-RP-91-1220

DECEMBER 18, 1991

REVISION 0

required). The whole waste form will be placed on the cutting floor and cut or sheared into appropriately sized pieces for the hopper of the baler. A grapple on another boom or crane will lift the pieces into the baler. Small pieces the grapple cannot 1 ift can be shoved with a scraper blade into a hopper for accumulation for transfer to the baler.

- Contact Handled Wastes (CHW)

Large pieces of contact handled wastes can also be cut with the mobile shears. Waste not suitable for shearing (i.e. process equipinent, etc) can be cui either with an acetylene torch or with a portable band saw. Portable exhaust systems will remove fumes generated by cutting torches to the ventilation system. A portable vacuum can collect sawdust and residues from the sorting and cutting area for processing with the waste to be treated. The pieces will be lifted into the baler with the grapple, or some other manual device, provided the baler will not cause cross-contamination of waste streams resulting in a more difficult treatment process. If the baler would cause cross-contamination resulting in more stringent disposal requirements, the cut up pleces of waste can be placed directiy into containers for further treatment.

\section{- Tritiated Wastes}

Tritiated wastes will be contact handled or handled with hoods or gloveboxes. A glovebox with a portable band saw (as opposed as to a industrial size bandsaw) or similar equipment wil: cut process equipment (i.e. mercury diftusion pumps) to expose the interior tubing to assist the mercury removal process with the added beirefit of size reduction. No further size reduction of tritiated wastes is plinned.

After sorting and cutting up large bulky wastes, the wastes would be sent to the next size reduction step required. The proposed size reduction module will contain a shredder and a 
MSRC-RP- $91-1220$

DECEMBER 18, 1991

REVISION 0

baler.

Combustible waste must be shredded and packed in cardboard containers, before it goes to the Consolidated Incineration Facility (CIF). The containers of combustible waste witl be -mptied into a shredder which will shred the waste into a size compatible with repacking into cardboard boxes meeting the CIF Waste Acceptance Criteria (WAC).

The packed boxes of shredded combustible waste will go to final assay (if required) and then to the CIF. There may be other waste streams roquiring shredding (as opposed to comipaction) prior to turther treatment in the HW/MW TB. These wastes would be shredded and placed back into a container for movement to the next applicable process station in the TB.

For the baling process a commercially available scrap metal baler will compress waste ilito a suitably sized bale (i.e. $\left.16^{\prime \prime} \times 16^{\prime \prime} \times 24^{\prime \prime}\right)$.

The baler would oject the bales onto an automatic roller conveyor or be lifted by an overhead conveyor to take the baled waste to the next treatment process.

After the size reduced and/or treated wastes are ready for movement or final disposal, wastes will be packed into disposal containers. Packing wastes will be primarily a personnel procedure. Operating personnel would lift the wastes with a commercially available lifter attached to a pneumatically powered hoist (or manually as necessary). The hoist must be capable of lifting 10 tons.

\subsubsection{The Macrot icapsulation Process}

Macroencapsulation is the process of surface coating a waste with a material such as polymeric organics or with a jacket of inert inorganic materials to substantially reduce surface exposure to potential leaching media. There is an EPA regulatory requirement to macroencapsulate radioactive lead solids and the HW/MW TB might possibly be able to macroencapsulate other waste streams. The recominended macroencapsulation process uses a thermoplastic polymer.

The process to macroencapsulate lead using thermoplastic polymers can be fully or partially automated or manually 
controlled. The amount of automation will be determined by the personnel protertion requirements and by an economic analysis.

The proposed process will have four processing stages:

- Sorting and sizing of lead

- The moplastic polymer coating of lead

- Final cooling and inspection of waste form

- Final packaging for disposal.

This process flow would take the lead from unsorted bulk waste lead to a inspected/certified waste form to be iransported to disposal vaults.

\subsubsection{Sorting and Sizing Lead}

At the sorting/size reduction module waste lead would be sorted into recyclable lead and lead to be macroencapsulated. The lead to be macroencapsulated would be placed into a baler/compactor and reduced into a standard specified size (i.e. 16" $\times 16^{\prime \prime} \times 6^{\prime \prime}$ ). A standard size will be the important parametur for the lead block (i.e. the weight and density of the block can vary). After compaction a heated stainiess steel screw thread eyebolt would be inserted into the lead block. The eyebolt would be heated to melt lead but not vaporize lead. This process would provide a secure method to transport the lead block without causing lead shavings or air emissions. Another alternative would be a stainless steei wire net to support the lead for the thermoplastic polymer treatment.

\subsubsection{Thermoplastic Polymer Macroencapsulation}

The standard size lead blocks would be lifted by the eyebolt, using an overhead conveyor, to a series of heated tanks containing molten polymer. The lead would be alternately dipped in the thermoplastic polymer and cooled until the desired thickness of coating is achieved (process is not unlike making a candle). The series of tanks would contain polymers of different colors ii.e. red, white, and biue) to ease the Quality Control (QC) checks of the 
WSRC-RP- $91-1220$

DECEMBER 18, 1991

REVISION 0

macroencapsulated lead. Inside the tanks would be a wire basket (similar to a french fry basket) to catch any pieces that could fall off the lead blocks during processing. These pieces would be placed back in the compactor to be reprocessed. The end product would be a block of lead covered in polymer with a eyebolt sticking out of the top ready for final cooling, inspection, and transport.

\subsubsection{Final Cooling and Inspection}

The blocks would continue to hang until the thermoplastic polymer is fully cooled and the coating is inspected. Any cracks or thin spots in the coating would be readily apparent to a visual inspection due to the different colors of thermoplastic polymers used in sequence in the coating process. The color seen through the crack would determine the depth of the crack. Any blocks failing inspection would be recycled through the thermoplastic polymer tanks until they pass. Any waste form that is destructively tested (i.e. cored) or the coating damaged in handling could be run through the tanks again to patch the damage.

\subsubsection{Packaging for Disposal}

The passed waste forms would be placed in disposal containers and any void space would be filled with a material (i.e. clean sand) to provide structural stability of the final waste form if the disposal container requires it. The lead blocks would be sized so the coated block can be efficiently placed in the disposal container.

\subsubsection{Stabilization / Solidification Process}

Stabilization / Solidification, as it relates to mixed waste, refers to transforming the wastes into a more manageable, less toxic, or non-leachable form. It involves the process of using cementitious binders or other binders for the immobilization of characteristic and listed metal constituents and radioactive contaminants. The leaching potential of the constituent of concern is reduced by isolating the contaminants from environmental influences by microencapsulating the waste particles. Solidification adds material to a liquid or semi-liquid waste to produce a solid 
monolith. Stabilization refers to the conversion of a waste to a more chemically stable form and includes use of a chemical reaction to transform the toxic components to a new, non-toxic compound or substance as toxicity is defined by TCLP. The regulatory requirement exists to treat selected wastes to Land Disposal Restriction (LDR) standards prior to disposal with solidification / stabilization being the Best Demonstrated Available Technology (BDAT).

The recommended alternative for the HW/MW TB will primarily use cementitious binders to treat wastes. The selected alternative provides the best flexibility based on the predicted wastes (soils and sludges) and economic viability. Incoming waste forms will be accumulated in storage containers or waste tanks to ensure economical processing. Consideration should be given to mixing similar coded wastes for a homogeneous mixture to ease processing. The mixture can then be pretreated as necessary to improve the stabilization / solidification process. Examples of pretreatment include $\mathrm{pH}$ adjustment, soil segregation, and contaminant removal to ensure a waste form meeting disposal criteria. The waste form would be slurried and then mixed with the cement grout in a process providing good shear and agitation. The grouted waste would then be poured into the disposal container for disposal.

The grout formulations would consist of mixtures of portland cement, flyash, slag, binders, and admixtures as required to stabilize/solidify the waste being treated. Since not all stabilization processes are compatible with all waste forms (i.e. high nitrate can inhibit cement solidification), bench-scale testing with waste forms would be necessary for optimum formulations. The cured waste form will require testing to verify it meets EPA and SRS disposal standards.

Some waste forms (i.e. mercury contaminated soils) are not suitable for a cement based system and will require a liquid polymer stabilization or other suitable treatment. These wastes are expected to be minor volumes and would be treated on a case by case basis. The significant increase in treatment costs makes these special processes undesirable for general use.

A process to recycle any stabilized material failing final analysis is required. The process will break up the waste form for reprocessing. Thorough waste characterization and specific formulations should minimize the failure rate. 
WSRC-RP-91-1220

DECEMBER 18, 1991

REVISION 0

The cement technology is readily available and is used routinely at Superfund sites. The polymer system is used in the nuclear waste industry at the present time.

\subsubsection{Radioactive Contaminated Mercury Waste Treatment}

The mercury wastes to be processed aro contaminated with tritium (a radioactive isotope of hydrogen). The treatment teshnologies for tritiated mercury waste are no different irom non-tritiated mercury waste. Tritiated mercury wastes will require careful control and separation from all other mercury wastes to minimize cross-contamination.

\subsubsection{Monitoring and Sorting Area Process Description}

The monitoring and sorting area will require the space to unpack contents, monitor, and sort. The anticipated size reduction module will contain only a bandsaw to cut up pumps and possibly process beds. Process equipment with mercury residue inside will be cut apart to expose the inner passageways to expedite the removal of mercury vapors before being placed into the mercury oven. Wastes requiring incineration will be repackaged (if needed) and sent to the CIF or interim storage as required.

The output of this module will be:

- Empty concrete culverts, drums, and stainless steel boxes for reuse or disposal as rad waste (level of radioactivity will determine where waste will be disposed).

- $\quad 0 i l s$ and other wastes suitable for incineration. They will be repackaged and processed (if required) for shipment to CIF. The oils will be transferred into drums or tanks for transportation to the CIF. The oils have to meet certain viscosity and pumpability requirements to be accepted at the CIF. Another strategy can be to sorb the oils (i.e. oil dry) and place into the 21 inch boxes meeting the CIF WAC. Additionally, oils and other burnable 
WSRC-RP- $91-1220$

DECEMBER 18, 1991

REVISION 0

wastes may require stockpiling to allow radioactivity to decay to the CIF WAC of 40 microcurie/mi before incineration. A permitted interim storage facility will be required for these wastes.

- $\quad$ Pumps and other process equipment already cutup and prepped for roasting and retorting.

- Process equipment needing no further treatment. It $w i l l$ be repackaged and sent to the appropriate disposal site.

The vast majority (>90\%) of the volume of these wastes will be in the first two categories.

\subsubsection{Roasting/Retorting Area}

Roasting/Retorting and recovery of high mercury wastes ( $\mathrm{Hg}>$ $260 \mathrm{ppm})$ is a specified technology, per EPA regulation 40 CFR 268 , before disposal of mercury wastes in the HW/MW Vaults.

The process to volatilize mercury from radioactive contaminated process equipment, soils, and other solid wastes with radioactive contaminated mercuiy has three major components:

- A Mercury Oven

- A Condenser/Decanter

- Offgas System with Tritium Removal

Each component will be required to process tritiated mercury wastes.

\section{Process Flow}

This is a brief description of the process required to roast/retort radioactive contaminated mercury from wastes. All of the technology to do this process exists and is used in the mercury industry and the DOE complex tritium facilities. 
The mercury oven will be sized, at a minimum, to handle cut apart 8 liter sprengle pumps, mercury diffusion pumps, and tritium process beds.

The condenser (i.e. chevron baffle trap or centrifugal trap) will be connected to the offgas system of the oven to coridense the mercury vapor. The Tiquid $\mathrm{Hg}$ would be drained off the bottom of the condensate receiver. Liquid organics would be decanted at the supernatant interface. The mercury will require further distillation, treatment, or amalgamation as necessary. The gas coming out of the condenser will be exhausted through the offgas system.

The offgas system will need the ability to remove any remaining mercury, tritium, organics, and any other undesirable air emissions.

Output

The expected output of the system will be elemental mercury to be amalgamated and process equipment suitable for RCRA disposal. If the waste is not classified as a high mercury waste $(\mathrm{Hg}>260 \mathrm{ppm})$ it will require testing before disposal.

\subsubsection{Amalgamation Area}

The amalgamation process will be a batch system sized to handle the annual projected volume of waste liquid $\mathrm{Hg}$ generated at SRS for disposal.

The mercury would be combined with zinc powder dampened with sulfuric acid to form an amalgam (EPA Procedure). This amalgam will be placed in specially designed stainless steel containers. These containers will have approximately a 2 gallon capacity and will have a machined screw closure to minimize vapor escape. The containers will weigh approximately 300 pounds when full ( $\approx 230$ pounds amalgamated mercury and $\approx 70$ pounds for the container).

The mercury would be drained into the two gallon container directiy from the oven condenser (mercury from other sources would arrive in the specified two gallon stainless steel container) and moved to the amalgamation area.

The containers of amalgam can then be placed in disposal containers and be ready for shipment to the HW/MW vaults. 
WSRC-RP-91-1220

DECEMBER 18, 1991

REVISION 0

Output

The only output from this area will be containers of amalgamated mercury.

\subsubsection{Acid Leaching and Chemical Precipitation}

Low mercury wastes have a Best Demonstrated Available Technology (BDAT) of acid leaching and chemical precipitation. The process should be capable of handling a wide variety of low volume wastes. The process would be capable of handling almost any heavy metal problem (i. e. chromium, etc).

Acid leaching and chemical precipitation is a liquid based batch treatment requiring:

$\begin{array}{ll}\text { - } & \text { Storage Tanks } \\ \text { - } & \text { Pcid Tanks } \\ \text { - Precipitant Chemical Tanks } & \text { Pre-Treatment Tanks } \\ \text { - Treatment Tanks } \\ \text { - Precipitation Tanks } \\ \text { - Piping and Valving to Support System } \\ \text { - A Sludge Dewatering System (i.e. centrifuge) }\end{array}$

\subsubsection{Wastewater Treatment Process}

Any wastewater generated at the HW/MW Treatment Building will have to be treated to the applicable disposal standards prior to final disposal. Processes generating wastewater will be minimized to the maximum extent possible.

The following processes are expected to generate wastewater in the HW/MW Treatment Facility:

- Decontamination process during normal operation.

- Cleanup activities between campaigns to minimize cross contamination and multiple waste code wastes.

- Size reduction and compaction.

- Macroencapsulation and stabilization.

- Analysis of wastes and treated waste forms. 
The wastewater generated will probably be a RCRA waste stream due to the "derived from rule." The wastewater will probably contain trace elements of regulated materials (i.e. lead, cadmium, mercury, organics, radionuclides). The actual composition of the waste water will vary depending on the generating source and waste going through processing. The capability to analyze wastewater to categorize treatment may be economically feasible. The other possibility is to determine a worst case wastewater content and treat all wastewater to that standard. The high cost of analys is makes this option attractive.

\section{PROCESS DESCRIPTION}

Wastewater will be accumulated in the storage tanks. Wastewater will be piped from the storage tanks to settling / storage tanks at the wastewater plant. The wastewater treatment plant would have 2 clarification / settling tanks, a inclined plate separator, a ultraviolet light system (biolngical inhibicor), a sand filter, and sludge handling / treatment equipment. The effluent will be piped to the recycle tank. The sludge will be solidified using a cement or similar solidification. The solidified waste forms will be $\mathrm{placed}$ in boxes and disposed in the HW/MW vaults. 
WSRC-RP-91-1220

DECEMBER 18, 1991

REVISION 0

\subsection{Final Treated Waste Descriptions}

\subsubsection{Contaminated Lead}

Treated contaminated lead will be $12^{\prime \prime} \times 12^{\prime \prime} \times 12 "\left(1 \mathrm{ft}^{3}\right)$ and coated in polymer. Each cube will weigh approximately 711 pounds. Approximately 19 lead blocks will fit into a B-12 sized box $\left(25 \mathrm{ft}^{3}\right)$ for a total weight of approximately 13,500 pounds.

\subsubsection{LETF Filter Paper}

LETF filter paper will be shredded and placed into 21" boxes for shipment to the CIF. Each box will weigh $180 \pm 25$ pounds (for mnisture content and packing efficiency variations).

\subsubsection{HEPA Filter Frames}

The metal hydroxide residue, with the $c d$, from the acid leaching process will be stabilized and placed in $96 \mathrm{ft}^{3}$ containers. A full container of stabilized waste will weigh approximately 17,000 pounds.

The cleaned steel frames will be compacted and placed in 96 $\mathrm{ft}^{3}$ containers. Each container has $90 \mathrm{ft}^{3}$ of waste space. There will be a $80 \%$ packing efficiency for a total of $72 \mathrm{ft}^{3}$ of steel frames. Each container will weigh approximately 27,000 pounds.

\subsubsection{Gold Mercury Traps}

Mercury traps will be disposed in stainless steel boxes inside $7^{\prime} \times 7^{\prime} 2^{\prime \prime}$ concrete culverts. They are presently stored in this manner.

Note: Repackaging into the standard $96 \mathrm{ft}^{3}$ may save on final disposal volume.

4.3.5 Mercury Soils, Sludges, Contaminated Soils, Floor Sweepings, CMP Soils, F\&H Seepage Bas in Groundwater Remediation Residues, Wastewater Treatment Sludges, and Plating Line Sump Waste.

Stabilized wastes will be in $96 \mathrm{ft}^{3}$ containers. Each container will contain $90 \mathrm{ft}^{3}$ of stabilized waste and weigh approximately 17,000 pounds. 
WSRC-RP-91-1220

DECEMBER 18, 1991

REVISION 0

\subsubsection{Tritiated Equipment and Process Beds}

Roasted and process sed equipment will be packed in $96 \mathrm{ft}^{3}$ containers holding $90 \mathrm{ft}^{3}$ of waste and weigh approximately 20,000 pounds.

\subsubsection{Mercury}

Anlalgamated mercury will be placed in commercially available mircury containers. The mercury containers will then be p) aced in $96 \mathrm{ft}^{3}$ containers for placement in the vaults. Each container is estimated to weigh 15,000 pounds.

\subsubsection{ITP Filters}

ITP filters will be in a specially designed container approximately $72 \mathrm{ft}^{3}$.

\subsubsection{Spent Tower Packing}

Wastes will be disposed in 55 gallon drums. They are presently stored in these containers.

Note: Variance will be required to dispose of in this manner.

\subsubsection{Containers and Packing Materials}

('ombustible material will be placed into 21 " boxes for shipment to the CIF.

size reduced material will be placed in $96 \mathrm{ft}^{3}$ containers holding $90 \mathrm{ft}^{3}$ of waste. Weight of this container will vary from 15,000 to 27,000 pounds depending on the actual waste material.

\subsubsection{Miscellaneous Wastes}

Wastes will be placed in $96 \mathrm{ft}^{3}$ containers holding $90 \mathrm{ft}^{3}$ of waste. Weight of this container will vary from 15,000 to 27,000 pounds depending on the actual waste material. 
WSRC-RP- $91-1220$

DECEMBER 18, 1991

REVISION 0

\subsection{PROCESS FLOW}

\section{HW/MWDF TREATMENT BUILDING MODERATE HAZARD PROCESS FLOW DIAGRAM 1.0 (TRITIATED WASTE PROCESS)}
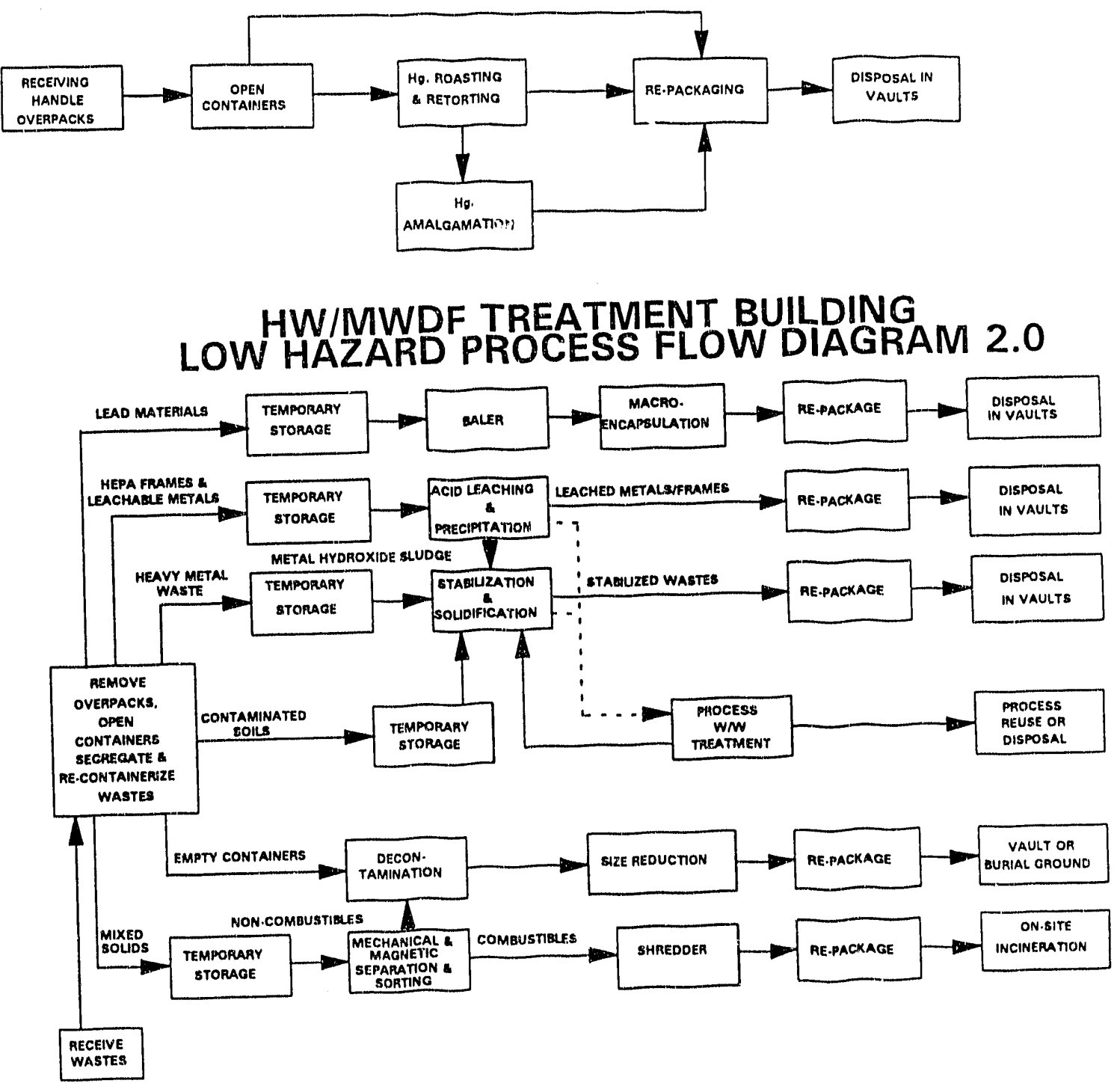


\subsection{THROUGHPUT AND DISPOSAL VOLUMES}

HW/MW PROCESSED WASTE DISPOSAL VOLUMES SUMMARY TABLE

\begin{tabular}{|c|c|c|}
\hline WASTE DESCRIPTION & $\begin{array}{c}\text { NUMBER OF } \\
\text { CONTAINERS } \\
4 \text { YRS/ALL YRS })\end{array}$ & $\begin{array}{c}\text { DISPOSAL VOLUME } \\
\left(1^{\text {ST }} 4 \text { YRS/ALL YRS }\right)\end{array}$ \\
\hline CONTAMINATED LEAD & $17 / 2$ & $1632 / 192$ \\
\hline TRITIATED EQUIPMENT & $4 / 2$ & $365 / 127$ \\
\hline CD PLATED HEPA FILTERS & $4 / 2$ & $345 / 146$ \\
\hline $\begin{array}{c}\text { CONTAINERS \& } \\
\text { PACKING MATERIAL }\end{array}$ & $70 / 40$ & $6250 / 3600$ \\
\hline STABILIZED WASTES & $380+/ 110+$ & $34,200+/ 10,000+$ \\
\hline MISCELLANEOUS WASTES & $1+$ & $10+$ \\
\hline MERCURY & $2 / 1$ & $192 / 96$ \\
\hline
\end{tabular}

WASTE DISPOSAL VOLUMES FOR DIRECT DISPOSAL IN HW/NW VAULTS

\begin{tabular}{|c|c|c|}
\hline WASTE DESCRIPTION & $\begin{array}{c}\text { NUMBER OF } \\
\text { CONTAINERS } \\
4 \text { YRS/ALL YRS })\end{array}$ & $\begin{array}{c}\text { WASTE VOLUME } \\
\left(1^{\text {ST }} 4 \text { YRS/ALL YRS }\right)\end{array}$ \\
\hline ITP FILTERS & $2 / 1$ & $144 / 72$ \\
\hline GOLD MERCURY TRAPS & $5 / 1$ & $270 / 10$ \\
\hline SPENT TOWER PACKING & $2 / 1$ & $125 / 5$ \\
\hline
\end{tabular}


WSRC - RP - 91- 1220

DECEMBER 18, 1991

REVISION 0

SECONDARY WASTE DISPOSAL VOLUMES

\begin{tabular}{|c|c|c|}
\hline WASTE DESCRIPTION & CONTAINERS & $\begin{array}{c}\text { WASTE VOLUME } \\
\mathrm{FT}^{3} \\
\text { (ALL YRS) }\end{array}$ \\
\hline $\begin{array}{c}\text { PROCESS } \\
\text { WASTEWATER SLUDGE }\end{array}$ & 12 & 1200 \\
\hline
\end{tabular}

RECYCLE VOLUMES

\begin{tabular}{|c|c|c|}
\hline WASTE DESCRIPTION & CONTAINERS & $\begin{array}{c}\text { RECYCLE VOLUME } \\
\mathrm{FT}^{3} \\
\left(1^{\text {sT }} 4 \text { YRS/ALL YRS }\right)\end{array}$ \\
\hline $\begin{array}{c}\text { CONTAINERS \& } \\
\text { PACKING MATERIAL }\end{array}$ & N/A & $1000 / 400$ \\
\hline WATER & N/A & $99,000 \mathrm{GPY}$ \\
\hline
\end{tabular}

WASTE VOLUMES FOR INCINERATION AT THE CIF

\begin{tabular}{|c|c|c|}
\hline WASTE DESCRIPTION & $\begin{array}{c}\text { NUMBER OF } \\
\text { CONTAINERS } \\
\left(1^{\text {sT }} 4 \text { YRS/A! L YRS }\right)\end{array}$ & $\begin{array}{c}\text { WASTE VOLUME } \\
\left(\mathrm{FT}^{3}\right) \\
\left(1^{\text {ST }} 4 \text { YRS/ALL YRS }\right)\end{array}$ \\
\hline LETF FILTER PAPER & $1020 / 500$ & $5100 / 2500$ \\
\hline $\begin{array}{c}\text { CONTAINERS \& } \\
\text { PACKING MATERIALS }\end{array}$ & $200 / 80$ & $1000 / 400$ \\
\hline
\end{tabular}


WSRC-RP-91- 1220

DECEMBER 18, 1991

REVISION 0

\subsection{Contaminated Lead}

INPUT

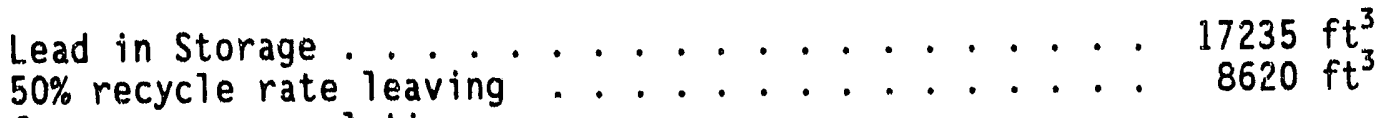

for macroencapsulation

A $25 \%$ work off rate (por the FFCA)......... $2155 \mathrm{ft}^{3}$ to be processed in the first 4 years

plus annual generation of ............ $175 \mathrm{ft}^{3}$

For a annual total of ............. $2330 \mathrm{ft}^{3}$

OUTPUT

Size reducing lead

will decrease volume by $50 \%$................ $1165 \mathrm{ft}^{3}$

Each $96 \mathrm{ft}^{3}$ container will hold $203.56 \mathrm{ft}^{3}$ blocks of lead

for a total of $71.2 \mathrm{ft}^{3}$ of lead per container.

$1165 \div 71=\ldots . . . . . . . . . . . .17$ Containers

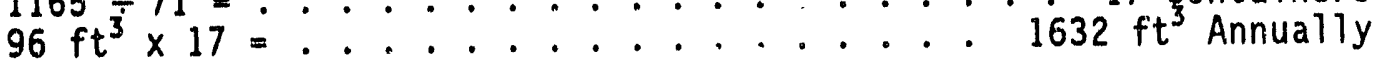

This total amount of lead will require processing during each of the first four years of eperation.

After the initial work off the rate will drop to $175 \mathrm{ft}^{3}$ annually.

Size reducing lead

will decrease volume by $50 \%$............. $90 \mathrm{ft}^{3}$

Each $96 \mathrm{ft}^{3}$ container will hold $203.5 \dot{\mathrm{ft}^{3}}$ blocks of lead

for a total of $71.2 \mathrm{ft}^{3}$ of lead per container.

$90 \div 71=.$. . . . . . . . . . . . . 2 containers

$96 \mathrm{ft}^{3} \times 2=$............................. $192 \mathrm{ft}^{3}$ Annually

\subsection{LETF Filter Paper}

INPUT

Filter Paper in Storage ............. $8400 \mathrm{ft}^{3}$ for shredding

A $25 \%$ work off rate (per the FFCA)......... $2100 \mathrm{ft}^{3}$ to be processed each of the first 4 years 
WSRC - RP- $91-1220$

DECEMBER 18, 1991

REVISION 0

plus annual generation of ............. $2000 \mathrm{ft}^{3}$

For a annual total of ............. $4100 \mathrm{ft}^{3}$

OUTPUT

Shredding and boxing

will increase volume by $25 \%$............ $5100 \mathrm{ft}^{3}$

Each 21 inch square container

will hold $5 \mathrm{ft}^{3}$ of shredded filters

for a annual total of ............. 1020 Boxes

This amount will require incineration at the CIF during each of the first four years of operation.

After the initial work off the rate will drop to $2000 \mathrm{ft}^{3}$ annually.

Shredding and boxing

will increase volume by $25 \%$............. $2500 \mathrm{ft}^{3}$

Each ?] inch square container

will hold $5 \mathrm{ft}^{3}$ of shredded filters

for a annual total of ............. 500 Boxes

\subsection{HEPA Filter Frames}

INPUT

Filter Frames in Storage ............ $1400 \mathrm{ft}^{3}$ for shredding and acid leaching

followed by stabilization of the removed $\mathrm{Cd}$

A $25 \%$ work off rate (per the FFCA) ......... $350 \mathrm{ft}^{3}$ to be processed each of the first 4 years

plus annual generation of ............. $250 \mathrm{ft}^{3}$

For a annual total of ............. . . $600 \mathrm{ft}^{3}$

OUTPUT

Shredding and acid leaching will remove $\approx 99 \%$ of the $\mathrm{Cd}$

for a total of $5 \%$ of the waste volume......... . $30 \mathrm{ft}^{3}$

Stabilization of cd doubles the volume 
WSRC-RP-91-1220

DECEMBER 18, 1991

REVISION 0

for a annual total of ....................... $60 \mathrm{ft}^{3}$

There will be $570 \mathrm{ft}^{3}$ of cleaned stainless steel frames for disposal at the SWDF or the HW/MW Vaults. Compaction should reduce this roughiy $50 \%$ to a annual volume of ..... $285 \mathrm{ft}^{3}$ After the initial work off the rate will drop to $250 \mathrm{ft}^{3}$ annually. Shredding and acid leaching will remove $\approx 99 \%$ of the $\mathrm{Cd}$ for a total of $5 \%$ of the waste volume .......... $13 \mathrm{ft}^{3}$

Stabilization of $c d$ doubles the volume for a annual total of ............... $26 \mathrm{ft}^{3}$

There will be $237 \mathrm{ft}^{3}$ of cleaned stainless steel frames for disposal at the SWDF or the HW/MW Vaults. Compaction should reduce this roughily $50 \%$ to a annual volume of ..... $120 \mathrm{ft}^{3}$

\subsection{Goid Mercury Traps}

Mercury traps in storage

for direct disposal in the first year......... $270 \mathrm{ft}^{3}$

plus annual generation of .............. $10 \mathrm{ft}^{3}$

For a annual total of ............... . . $280 \mathrm{ft}^{3}$

After the initial work off the rate will drop to $10 \mathrm{ft}^{3}$ annually for direct disposal.

6.5 Mercury Soils, Sludges, Contaminated Soils, Floor Sweepings, CMP Soils, F\&H Seepage Basin Groundwater Remediation Residues, Wastewater Treatment Sludges, and Plating Line Sump Waste.

INPUT

Material in storage for stabilization............................ $48275 \mathrm{ft}^{3}$

A $25 \%$ work off rate (per the FFCA)........ $12100 \mathrm{ft}^{3}$ to be processed in the first 4 years

plus annual generation of ........... 5000+ $\mathrm{ft}^{3}$ 
WSRC - RP-91- 1220

DECEMBER 18, 1991

REVISION 0

For a annual total of ............ $17100+\mathrm{ft}^{3}$

NOTE: Soil washing could reduce this volume

\section{OUTPUT}

Approximately $90 \mathrm{ft}^{3}$ of stabilized waste will be stored in $96 \mathrm{ft}^{3}$ containers.

$34200+\div 90=$..........380+ Containers Annually

This amount of material will require processing during the first four years of operation.

After the initial four years work off the rate will drop to $5000+$ $\mathrm{ft}^{3}$ annually for stabilization and disposal.

Stabilization doubles the volume

for an annual volume of ....... 10,000+ $\mathrm{ft}^{3}$ $10,000+\mathrm{ft}^{3} \div 90=$.......... 110+Containers Annually

6.6 Tritiated Equipment and Process Beds

INPUT

Equipment in storage $900 \mathrm{ft}^{3}$

for roasting/retorting

A $25 \%$ work off rate (per the FFCA) . . . . . . $225 \mathrm{ft}^{3}$ to be processed each of the first 4 years

plus annual generation of ........... $120 \mathrm{ft}^{3}$

For a annual total of ....................... $345 \mathrm{ft}^{3}$

OUTPUT

Roasting and Retorting will

remove $1 \% \mathrm{Hg}$

Amalgamation of $\mathrm{Hg}$ increases the volume 
by a factor of 6 for a annual total of ....... $20 \mathrm{ft}^{3}$

There will be $345 \mathrm{ft}^{3}$ of roasted equipment for disposal at the SWDF or the HW/MW Vaults, Waste will be packed in $96 \mathrm{ft}^{3}$ containers holding $90 \mathrm{ft}^{3}$ of waste for a annual total of ................. 4 containers

This amount of materi:l will require processing during the first four years of operation. After the initial four years work off the rate will drop to a annual generation of ............ $120 \mathrm{ft}^{3}$

Roasting and Retorting will remove $1 \% \mathrm{Hg} \ldots \ldots . \ldots \mathrm{ft}^{3}$

Amalgamation of $\mathrm{Hg}$ increases the volume by a factor of $\epsilon$ for a annual total of ....... $7 \mathrm{ft}^{3}$

There will be $120 \mathrm{ft}^{3}$ of roasted equipment for disposal at the SWDF or the HW/MW Vaults, Waste will be packed in $96 \mathrm{ft}^{3}$ containers holding $90 \mathrm{ft}^{3}$ of waste for a annual total of ............. 2 containers

\subsection{Mercury}

INPUT

Mercury in storage for amalgamation ............ $15 \mathrm{ft}^{3}$

A $25 \%$ work off rate (per the FFCA) ........ $4 \mathrm{ft}^{3}$ to be processed each of the first 4 years

plus annual generation of ........... $15 \mathrm{ft}^{3}$

For a annual total of ............ $19 \mathrm{ft}^{3}$ OUTPUT

Amalgamation of $\mathrm{Hg}$ increasas the volume by a factor of 6 for a annual total of ...... $114 \mathrm{ft}^{3}$ Anialgamated mercury containers will be placed in $96 \mathrm{ft}^{3}$ containers holding $90 \mathrm{ft}^{3}$ of waste for a annual total of ............ 2 containers 
WSRC-RP-91-1220

DECEMBER 18, 1991

REVISION 0

This amount of material will require processing during the first four years of operation. After the initial work off the rate will drop to $15 \mathrm{ft}^{3}$ annually.

Amalgamation of $\mathrm{Hg}$ increases the volume by a factor of 6 for a annual total of ......... $90 \mathrm{ft}^{3}$ Amalgamated mercury containers will be placed in $96 \mathrm{ft}^{3}$ containers holding $90 \mathrm{ft}^{3}$ of waste for a

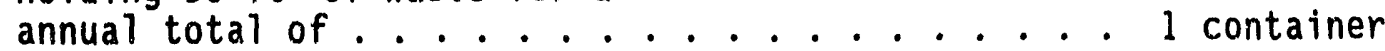

\subsection{ITP Filters}

ITP filters in storage

for direct disposal in the first year........ $72 \mathrm{ft}^{3}$

plus annual generation of ............ $72 \mathrm{ft}^{3}$

For a annual total of .................. $144 \mathrm{ft}^{3}$

After the initial work off the rate will drop to $72 \mathrm{ft}^{3}$ annually for direct disposal.

\subsection{Spent Tower Packing}

Spent Tower Packing in storage

for direct disposal in the first year........ $125 \mathrm{ft}^{3}$

plus annual generation of ............. $5 \mathrm{ft}^{3}$

For a annual total of ............ $130 \mathrm{ft}^{3}$

After the initial work off the rate will drop to $5 \mathrm{ft}^{3}$ annually for direct disposal.

\subsection{Containers and Packing Materials}

INPUT

Material in storage . . . . . . . . . . $20,000 \mathrm{ft}^{3}$

$5 \%$ recycle rate ................. - $-1000 \mathrm{ft}^{3}$

$5 \%$ incineration rate ............................... $1000 \mathrm{ft}^{3}$

Total in storage .............................. $1800 \mathrm{ft}^{3}$ 
WSRC-RP- $91-1220$

DECEMBER 18, 1991

REVISION 0

A $25 \%$ work off rate (per the FFCA) ........ $4500 \mathrm{ft}^{3}$ to be processed each of the first 4 years

plus annual generation of ............. $8000 \mathrm{ft}^{3}$

For a annual total of ............. $12500 \mathrm{ft}^{3}$

OUTPUT

Size reducing

will decrease volume by $50 \%$........... . $6250 \mathrm{ft}^{3}$

Each $96 \mathrm{ft}^{3}$ container will hold $90 \mathrm{ft}^{3}$ of waste.

$6250 \div 90=$............. 70 Containers Annually

The containers would go to the SWDF or the HW/MW Vaults.

This amount of material will require processing during each of the first four years of operation.

After the initial work off the rate will drop to $8000 \mathrm{ft}^{3}$ annually.

Annual total .................. . . $8000 \mathrm{ft}^{3}$

$5 \%$ recycle rate
$5 \%$ incineration rate...
.

Total

$7200 \mathrm{ft}^{3}$

Size reducing

will decrease volume by $50 \%$.............. $3600 \mathrm{ft}^{3}$

Each $96 \mathrm{ft}^{3}$ container will hold $90 \mathrm{ft}^{3}$ of waste.

$3600 \div 90=$.............. 40 Containers Annually

The containers would go to the SWDF or the HW/MW Vaults. 
WSRC-RP- $91-1220$

DECEMBER 18, 1991

REVISION 0

\subsection{Wastewater Treatment}

\section{INPUT}

100,000 gallons wastewater with $2 \%$ solids

produces ............... $535 \mathrm{ft}^{3}$ of waste

\section{OUTPUT}

Stabilization doubles the volume

for an annual volume of ............. $1070 \mathrm{ft}^{3}$

Each $96 \mathrm{ft}^{3}$ container will hold $90 \mathrm{ft}^{3}$ of waste. $1070 \div 90=$............ 12 Containers Annually

The containers would go to the HW/MW Vaults.

The wastewater plant effluent will be returned to the recycle tank for recycling. 
WSRC-RP-91-1220

DECEMBER 18, 1991

REVISION 0

\subsection{REFERENCES}

1.0 SRS Mixed Waste Characterization Catalog for the HW/MW DF, WSRCTR-90-2̂́. M.S. Hay, et. al., May 31, 1990.

2.0 HW/MW DF - Recommended Treatments and Related Waste Management Issues (U), WSRC-RP-90-1143, C.A. Langton, et. aT., November 16, 1990 .

3.0 Hazards Assessment Document - HW/MW Treatment Building (U), Line Item 89-D-175,G.B. Woolsey, June 12, 1991.

4.0 HW/MW DF Phase II Treatment Building Basic Data Report, WSRC-TR91-120, L.L. Bailey, March 28, 1991.

5.0 "Review of the SRS Solid Waste Forecast -FY 92", NMP-WMO-91-0155, M.E. Gorden, September 17, 1991.

6.0 Core Treatment Recommendations for the HW/MW TSB (U), WSRC-TR-90602, J.L. England, December 26, 1990.

7.0 HW/MW DISPOSAL FACILITY-Phase 2 Waste Processing Building Basic Data, Revision 1, OPS-WMP-89-2512, M.S. Peters \& C.B. Stevens, July 25, 1989.

8.0 Cost Assessment of Processing Tritiated Mercury Waste (U), WSRCRP-91-724, J.L. England, August 23, 1991.

9.0 A Perspective of Hazardous Waste and Mixed Waste Treatment Technology at the SRS (U), WSRC-MS-91-117, J.L. England et. a)., June 28, 1991.

\subsection{ACKNOWLEDGEMENTS}

The following people provided input to the development to this document. Their assistance was crucial to the completion of this document.

L. Baitey

G. Beaumier

D. Noller

S. Venkatesh

In addition numerous vendors and suppliers provided information used in the compilation of this study. 

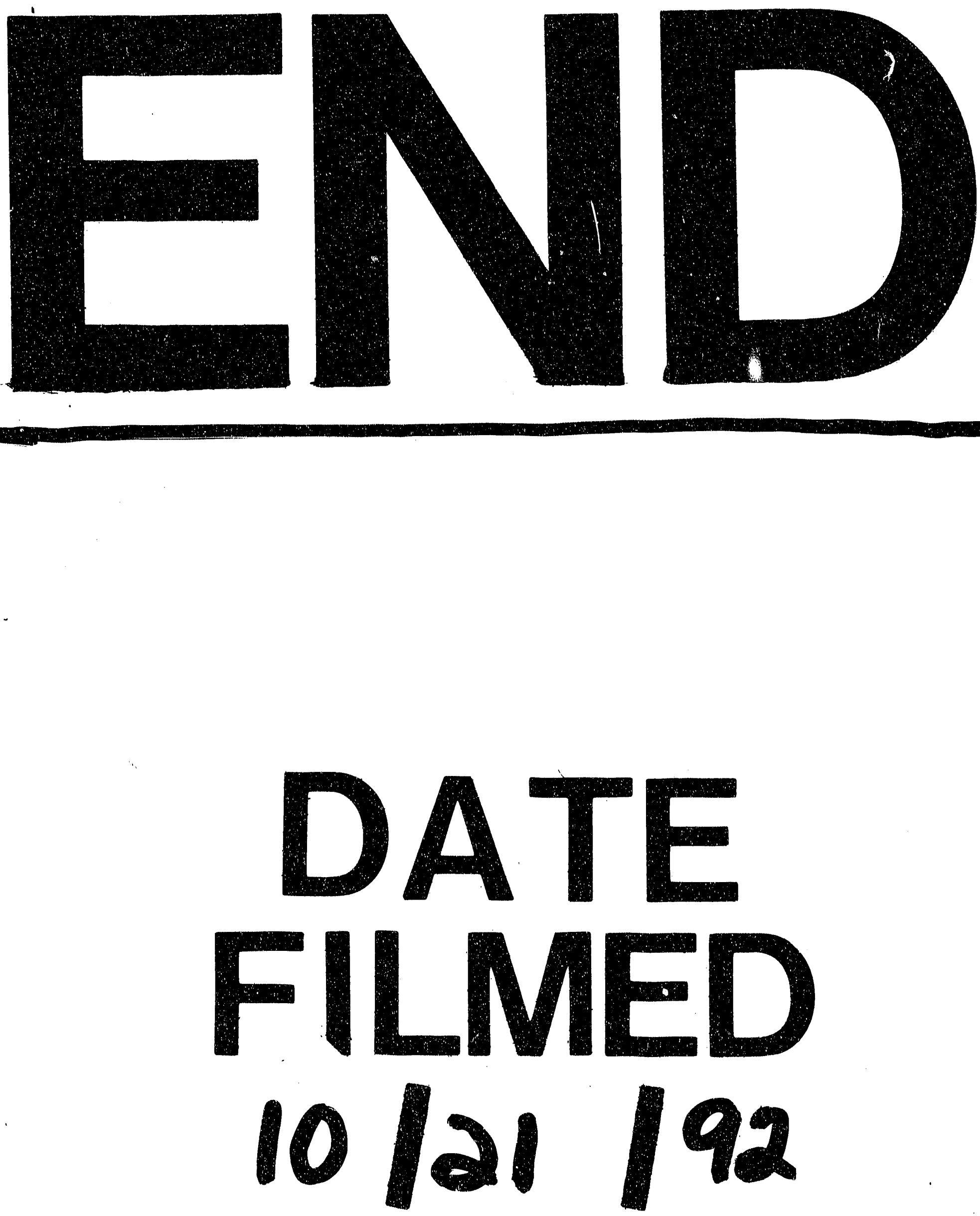
